\title{
An Association of Serum ferritin and SGPT Level in Transfusion dependent Thalassaemia major Patients-A Cross Sectional Study
}

\author{
F Parvin ${ }^{1}$, B Naznin ${ }^{2}$, T T Chowdhury ${ }^{3}$, AFM A Imran ${ }^{4}$, M L Nahar ${ }^{5}$, S A Hossain ${ }^{6}$
}

Abstract

Background: The Thalassaemia is an inherited haemoglobulin disorder causes hemolytic anemia which usually requires life-long blood transfusion therapy. Therefore transfusion dependent thalassaemia major patients suffer from the effect of deposition of excess iron in the liver, heart and endocrine glands.

Objective : The aim of present study was to find out the association of serum ferritin and SGPT in transfusion dependent thalassaemia major patient.

Methodology: This cross sectional study was carried out in Day care unit (DCU) of Transfusion Medicine department, Bangabandhu Sheikh Mujib Medical University (BSMMU), Dhaka, during January 2014 to December 2014. Total of 110 clinically diagnosed Thalassaemia major (TM) between (5.35 years) cases of either sex from the above mentioned department attending the DCU were selected purposively for this study. Data were collected on clinical examination

1 Dr. Farida Parvin Assistant Professor Dept. of Transfusion Medicine Enam Medical College, Savar

${ }^{2}$ Dr. Bepasha Naznin Resident

Dept. of Transfusion Medicine BSMMU, Dhaka

${ }^{3}$ Dr. Tanzila Tabib Chowdhury Assistant Registrar Pediatric haematooncology Chittagong Medical College Hospital

${ }^{4}$ Dr. AFM Ashik Imran Lecturer, Biochemistry Ad-din Women's Medical College

${ }^{5}$ Dr. MST. Laizuman Nahar Lecturer, Pathology Pediatric haematooncology Ad-din Women's Medical College

${ }^{6}$ Prof. Dr. SK. Akbar Hossain Professor \& Head Dept. of Community Medicine \& Principal

Shahabuddin Medical College

Correspondence

Dr. Farida Parvin

Assistant Professor

Dept. of Transfusion Medicine

Northern International Medical

College, Dhaka

email: dr.farida1984@gmail.com findings, laboratory investigations, ABO and Rh Blood Group, Serum ferritin and SGPT (Serum glutamic pyruvic transaminase) after taking informed consent.

Results : The following observations and results were obtained in this study. The mean age was found $17.15 \pm 8.77$ years with range from 5 to 35 years and male to female ratio was 1.2:1 (male 59 and female 51). Sixty eight $(68.0 \%$ ) patients came from rural area, $43.6 \%$ patients were student, $77.3 \%$ patients had completed primary education, $57.3 \%$ of the patients came from middle class family and $72.7 \%$ patients were unmarried. About $46.4 \%$ of the patients had moderate anaemia, $28.2 \%$ had jaundice, $79.1 \%$ had hepatomegaly, $82.7 \%$ had splenomegaly and $30.9 \%$ had complication due to iron overload. Mean haemoglobulin $(\mathrm{Hb} \%)$ was found $6.65 \pm 1.63 \mathrm{gm} / \mathrm{dl}$, mean serum ferritin was found $3785 \pm 17637 \mu \mathrm{g} / \mathrm{L}$ and mean SGPT was found $134.8 \pm 77.94 \mathrm{U} / \mathrm{L}$. There was a significant positive correlation $(r=0.259 ; p=0.006)$ between serum ferritin and SGPT.

Conclusion : Considering the study result it can be concluded that there is a positive significant correlation between serum ferritin with SGPT level.

Northern International Medical College Journal Vol. 8 No. 01 July 2016, Page 170-173

\section{Introduction}

Thalassaemia is the most common genetic blood disorder and its incidence varies in different population group of the world. An overview of the global distribution of thalassaemia shows that in addition to the Mediterranean countries in which they were first recognized, thalassaemia are frequently found in Asia and the Far East. World Health Organization (WHO) estimates that at least $6.5 \%$ of the world populations are carriers of different inherited disorders of haemoglobin ${ }^{1}$. Another WHO reports estimates that 3\% are carriers of beta thalassaemia major and $4 \%$ are carriers of $\mathrm{HbE}$ in Bangladesh out of 7000 new born babies. In Bangladesh, more than 7000 children are born with thalassaemia each year. ${ }^{2}$

Despite the increased life expectancy of thalassaemia patients complications of the disease is keep arising ${ }^{3}$. Frequent blood transfusion in thalassaemia major carry the adverse effect of iron build up in the body ${ }^{4}$. Thus repeated blood transfusion in thalassaemic patients is a double edges sword $^{5}$. Iron overload may damage the liver, heart and endocrine glands leading to debilitating and life threatening problems ${ }^{6}$.

Even though the primary genetic defect resides in a single gene (i.e., beta globins) expressed only during terminal maturation of red cell progenitors, many organ systems are affected. Patients of thalassaemia suffer 
simultaneously from severe and chronic anemia, the stigmata of chronic hemolysis, organ damage from transfusional iron overload, the profound local systemic effects of a rapidly and relentlessly expanding mass of erythroid bone marrow progenitor. $^{7}$

Determination of the liver iron concentration is still regarded as the best predictor of total body iron, but the procedure is invasive and has risks. Quantitative, non-invasive methods for measuring body iron are needed that are safe, accurate and readily available. Iron overload is caused by increased intestinal absorption or by blood transfusions. The effective management of iron overload requires frequent evaluation of body iron stores. Measurement of serum ferritin, although easy to perform, gives results that are too variable for the accurate prediction of total body iron.

Liver disease is common in thalassaemia major patients and severe haemochromatosis is still observed in $30-40 \%$ of patients despite iron chelation. ${ }^{8}$ The prevalence of cirrhosis is reported to be $10-40 \%{ }^{9}$ and the prevalence of liver fibrosis is about $40-80 \% .{ }^{10}$ Though the number of reported deaths from liver disease in thalassaemia major is small, severe haemosiderosis and hepatic fibrosis may lead to cirrhosis. Early and accurate diagnosis of liver disease followed by prompt intervention may prevent liver disease progression.

The aim of this study was to understand the association between serum ferritin and SGPT in transfusion dependent thalassaemia major patients.

\section{Materials and Methods}

This cross sectional study was carried out to find out the effect of iron over load on liver function in transfusion dependent thalassaemia major patients. A total of 110 clinically diagnosed case of thalassaemia major patients attending the Day care unit (DCU) of Transfusion Medicine department of Bangabandhu Sheikh Mujib Medical University, Dhaka during January 2014 to December 2014, were selected purposively for this study.

The inclusion criteria were -

i) patients of 5 to 35 years and of both sexes

ii) all blood transfusion dependent thalassaemia cases confirmed by history, clinical exam and $\mathrm{Hb} \%$ electrophoresis

iii) duration of transfusion of each case must be 5years or more

iv) patient who gave consent or whose attendant gave consent to comply the study procedure

Exclusion criteria were i) patients age less than 5 years and more than 35 years,

ii) who had chronic liver disease due to other causes,

iii) started iron chelation therapy

iv) patients who were unwilling to give informed consent to take part in the study

The preliminary screening for each patient was completed on taking history, doing physical examination and the necessary laboratory tests. Data were collected on clinical examination findings, laboratory investigations, ( $\mathrm{BBO}$ and $\mathrm{Rh}$ Blood Group, $\mathrm{Hb} \%$, Serum ferritin and Serum glutamic pyruvic transaminase (SGPT).

\section{Results}

In the present study it was observed that $51(46.4 \%)$ patients had moderate anaemia, 31(28.2\%) had jaundice, 27(24.5\%) had mild oedema, 101(91.8\%) had normal pulse (60-90 beats/min), 105(95.5\%) had normal blood pressure (Systolic BP 110-140/ Diastolic BP $60-90 \mathrm{mmHg}), 100(90.9 \%)$ had normal temperature $\left(97-99^{\circ} \mathrm{F}\right), 87(79.1 \%)$ had hepatomegaly, $91(82.7 \%$ ) had splenomegaly (Table I).

Table I : Distribution of the study patients by clinical examination $(n=110)$

Clinical examination Number of patients Percentage

Anaemia

Mild

Moderate

Severe

Jaundice

Yes

No

Oedema

Mild

Moderate

Nil

Pulse beats/min

Normal $(60-90 / \mathrm{min})$

Tachycardia (>90/min)

35

31.8

46.4

21.8

24

28.2

71.8

79

24.5

1.8

73.6

Blood pressure (BP)

Normal

(Systolic BP 110-140/Diastolic

105

95.5

BP $60-90 \mathrm{mmHg}$ )

Hypertensive

(Systolic BP $>140$ /

5

4.5

Temperature

Normal $\left(97-99^{\circ} \mathrm{F}\right) \quad 100$

90.9

Liver

High $\left(\geq 100{ }^{\circ} \mathrm{F}\right)$

9.1

Hepatomegaly

79.1

Spleen

Not enlarged

87

20.9

Splenomegaly

82.7

9

Not palpable 
Hepatomegaly-Palpation of liver $2 \mathrm{~cm}$ below the costal margin Splenomegaly-Mild: $<4 \mathrm{~cm}$, Moderate: 4 to $8 \mathrm{~cm}$,Severe: $>8 \mathrm{~cm}$ from the left costal margin along its long axis.

Regarding blood group and Rh typing of the patients, it was observed that each blood group of $O$ and $B$ patients were 37 (33.6\%). Rh type positive was found in $106(96.4 \%)$ patients (Table II).

\section{Table II: Distribution of the study patients by blood group $(n=110)$}

$\begin{array}{lcc}\begin{array}{l}\text { Blood group with Rh typing } \\ \text { Blood group }\end{array} & \text { Number of patients } & \text { Percentag } \\ \text { A } & & \\ \text { B } & 24 & 21.8 \\ \text { AB } & 37 & 33.6 \\ \text { O } & 12 & 10.9 \\ \text { Rh typing } & 37 & 33.6 \\ \text { Positive } & & \\ \text { Negative } & 106 & 96.4 \\ \end{array}$

Haemoglobulin percentage of patients showed that $65(59.0 \%)$ patients had $\mathrm{Hb} \% 1-6 \mathrm{gm} / \mathrm{dl}$. The Mean $\mathrm{Hb} \%$ was found $6.65 \pm 1.63 \mathrm{gm} / \mathrm{dl}$ with range from 2 to $9 \mathrm{gm} / \mathrm{dl}$. (Table III).

\section{Table III : Haemoglobulin percentage ( $\mathrm{Hb} \%)$ of the study patients $(n=110)$

$\begin{array}{ccc}\begin{array}{c}\text { Haemoglobulin percentage } \\ \text { Hb\% (gm/d) }\end{array} & \text { Number of patients } & \text { Percentage } \\ 1-6 & 65 & 59.0 \\ 7-9 & 45 & 41.0\end{array}$

Mean \pm SD $6.65 \pm 1.63$

Biochemical investigations of the patients, it was observed that $108(98.2 \%)$ patients had serum ferritin $>1000 \mu \mathrm{g} / \mathrm{L}$ and mean serum ferritin was $3785 \pm 17637 \mu \mathrm{g} / \mathrm{L}$. Regarding SGPT, $101(91.8 \%)$ had SGPT $51-500 \mathrm{U} / \mathrm{L}$ and mean SGPT was 134.8 $\pm 77.94 \mathrm{U} / \mathrm{L}$ (Table IV).

\section{Table IV: Biochemical investigations of the study patients $(n=110)$}

Biochemical investigations

Number of patients Percentage

Serum ferritin $(\mu \mathrm{g} / \mathrm{L})$

$\begin{array}{lcc}200-1000 & 2 & 1.8 \\ >1000 & 108 & 98.2\end{array}$

Mean \pm SD $3785 \pm 2406$

SGPT (U/L)

$\begin{array}{lcc}35-50 \mathrm{U} / \mathrm{L} \text { (normal) } & 9 & 8.2 \\ 51-500 \mathrm{U} / \mathrm{L} & 101 & 91.8\end{array}$

Mean \pm SD $134.8+77.94$

A significant positive correlation $(r=0.259 ; p=0.006)$ between serum ferritin and SGPT.

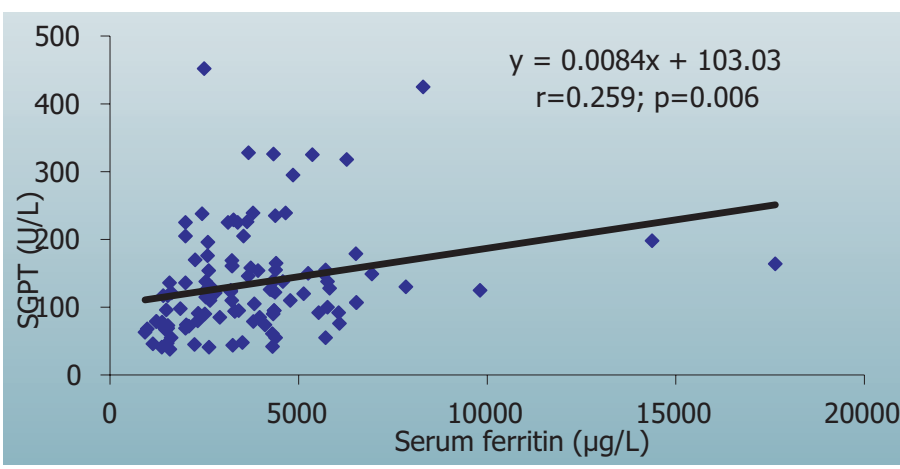

Figure 1 : Scatter diagram showing positive correlation $(r=0.259$ $p=0.006$ ) between serum ferritin and SGPT

\section{Discussion}

Thalassaemia major is characterised by inadequate globin chain synthesis, leading to ineffective erythropoiesis, severe anaemia and chronic disease in adulthood. ${ }^{11}$ In this study it was observed that $51(46.4 \%)$ patients had moderate anaemia, 31(28.2\%) had jaundice, 27(24.5\%) had mild oedema, 101(91.8\%) had normal pulse (60-90 beats/min), $105(95.5 \%)$ had normal blood pressure (SBP 110-140/DBP $60-90 \mathrm{mmHg}), 100(90.9 \%)$ had normal temperature (97$\left.99^{\circ} \mathrm{F}\right), 87(79.1 \%)$ had liver enlarged, $91(82.7 \%)$ had spleen palpable. Veglio et al. (1998) observed in their study that more than $9(40 \%)$ of the thalassaemia major patients did not show a significant diurnal BP and HR rhythm. ${ }^{12}$ In thalassaemia major patients, the overall amplitude of systolic $B P$, diastolic $B P$, and $H R$ was significantly lower than in controls $(P<0.05)$.

In this current study it was observed that $37(33.6 \%)$ patients was found blood group $\mathrm{O}$ and $\mathrm{B}$ respectively. Rh type was positive in 106 (96.40\%) patients. Mean $\mathrm{Hb} \%$ was found $6.65 \pm 1.63 \mathrm{gm} / \mathrm{dl}$, mean serum ferritin was found $3785 \pm 17637 \mu \mathrm{g} / \mathrm{L}$ and mean SGPT was found $134.8 \pm 77.94$ U/L. Riaz et al. (2011) observed Blood group "O" was to be the predominant in 39(49.4\%), Blood group $A$ was found $17(21.6 \%)$, Blood group B was 21(26.4\%), Blood group AB was $2(2.6 \%)$ and the mean serum Ferritin level in their study were $4236.5 \mathrm{ng} / \mathrm{ml} .{ }^{13}$ Yin et al (2011) reported 56(44.6\%) of patients maintained their hemoglobin levels $>9.0 \mathrm{~g} / \mathrm{dl}^{14}$. Shamshirz et al (2003) reported hemoglobin level before transfusion about $9.6 \pm 2.3 \mathrm{~g} / \mathrm{dl}^{15}$.

In our study mean serum ferritin was found $3785 \pm 17637 \mu \mathrm{g} / \mathrm{L}$. Li et al. (2012) reported serum ferritin levels from the minimum of $1500 \mathrm{ng} / \mathrm{mL}$ up to a maximum of $11491 \mathrm{ng} / \mathrm{mL}^{16}$ Belhoul et al. (2012) reported the mean serum ferritin level $2597.2 \pm 1976.8 \mu \mathrm{g} / \mathrm{I}^{17}$ Cunningham et al. 
(2004) reported ferritin levels from 147 to $11010 \mathrm{ng} / \mathrm{mL}$ (median, $1696 \mathrm{ng} / \mathrm{mL}$ ). ${ }^{18}$ Mazza et al. (1995) reported ferritin levels between 276 and $8031 \mathrm{ng} / \mathrm{mL} .{ }^{19}$ Berak et al. (2004) reported ferritin levels $2171.5 \pm 1439.8(103-5150 \mathrm{ng} / \mathrm{m}) .^{20}$ Mansouri-targhabeh and Badie (2004) reported ferritin levels $2597 \pm 1976 \mathrm{ng} / \mathrm{mL} .{ }^{21}$ The above findings are comparable with this study. In this study it was observed a positive significant correlation $(r=0.259 ; p=0.006)$ between serum ferritin with SGPT. Similarly, a research on 104 patients with beta Thalassaemia major Hashemizadeh et al. (2012) showed a significant correlation between iron level as indicated by transferrin saturation or serum ferritin levels and SGOT, SGPT levels. ${ }^{22}$

\section{Conclusion}

This study was undertaken to find out the association of serum ferritin and SGPT in transfusion dependent thalassaemia major patient. Majority of the patients were in 2nd decade and male predominant and there was a positive significant correlation between serum ferritin with SGPT level.

\section{References}

1. Modell B.'Update to epidemiology of haemoglobin disorder', Thalassaemia International Federation, 1995; 5; 247-58.

2. Khan, W A,'Thalassaemia in Bangladesh', DS(children) Hospital J.1991; $15 ; 42-4$.

3. Hoffband A $\vee$ 'A sensitive test for early myocardial iron loading', Eur Heart J.2003; 24;26-7.

4. Seksarl $P$, Chotivittayatarakorn $P$, Pathmanand $C$ and Sueblinvong V, 'Cardiac dysfunction in beta thalassaemic children', J Med Assoc Thai 1993; 76; 591-6.

5. Shah N, Mishra A, Chauhan D, Vora C and Shah N R, 'Study on effectiveness of transfusion program in Thalassaemia major patients receiving multiple blood transfusions at a transfusion centre in Western India', Asian J Transfus Sci 2010; 4(2); 94-98.

6. Porter J B, 'Practical management of iron overload', Br J haematology 2001; 115(2); 239-52.

7. Olivieri NF, 'The beta-Thalassaemias', N Engl J Med 1999; 341; 99.

8. Cunningham MJ, Macklin EA, Neufeld EJ and Cohen AR, 'Thalassaemia Clinical Research Network. Complications of beta-Thalassaemia major in North America', N A Blood journal2004; 104(1); 34-9.
9. Jean G, Terzoli S, Mauri R, Borghetti L, Di Palma A and Piga A, 'Cirrhosis associated with multiple transfusions in thalassaemia', Arch Dis Child1984; 59; 67-70.

10. Maurer HS, Lloyd-Still JD, Ingrisano C, Gonzalez-Crussi F and Honig GR, 'A prospective evaluation of iron chelation therapy in children with severe beta-Thalassaemia A six-year study', Am J Dis Child1988; 142; 287-92.

11. Ali SS, Tarawah AM, Al-Hawsawi ZM, Zolaly MA and Turkustani W, 'Comprehensive patient care improves quality of life in transfusion dependent patients with -Thalassae mia', Saudi Med J 2015;. 36(5); 575-579.

12. Veglio F, Melchio R, Rabbia F, Molino P, Genova GC and Martini G, 'Blood pressure and heart rate in young Thalassaemia major patients', Am J Hypertens1998;. 11(5); 539-47

13. Riaz H, Riaz T, Khan MU, Aziz S, Ullah F and Rehman A, 'Serum ferritin levels, socio-demographic factors and desferrioxamine therapy in multitransfused Thalassaemia major patients at a government tertiary care hospital of Karachi, Pakistan', BMC Res Notes211;. 4;287.

14.Yin XL, Wu ZK, He YY, Zhou TH and Zhang XH, 'Treatment and complications of Thalassaemia major in Guangxi, Southern China', Pediatric Blood \& Cancer2011; 57(7); 1174-1178.

15. Shamshirsaz AA, Bekheirnia MR, Kamgar M, Pourzahedgilani N, Bouzari $\mathrm{N}$ and Habibzadeh MR, 'Metabolic and endocrinologic complications in beta-Thalassaemia major: a multicenter study in Tehran', BMC Endocr Disord2003; 3(4); 1-6.

16. Li CG, Liu SX, Mai HR, Wang Y, Wen FQ and Liu RY, 'Evaluation of heart and liver iron deposition status in patients with -Thalassaemia intermedia and major with MRI T2 technique', Zhongguo Dang Dai ErKeZaZhi2012; 14(2); 110-3.

17. Belhoul KM, Bakir ML, Saned MSE, Kadhim AMA, Musallam KM and Taher AT, 'Serum ferritin levels and endocrinopathy in medically treated patients with Thalassaemia major', Annals of Hematology2012; 91(7);1107-14.

18. Cunningham MJ, Macklin EA, Neufeld EJ and Cohen AR, 'Thalassaemia Clinical Research Network. Complications of beta-Thalassaemia major in North America', N A Blood journal2004;. 104(1); 34-9.

19. Mazza P, Giua R, De Marco S, Bonetti MG, Amurri B and Masi C, 'Iron overload in Thalassaemia: comparative analysis of magnetic resonance imaging, serum ferritin and iron content of the liver', Haematologica j1995; 80(5); 398-404.

20. Berak M, Mirzarahimi $M$ and Habibzadeh $H$, 'Endocrine omplications in patients of beta Thalassaemia major in li Asghar hospital in Ardabil', Unpublished PhD. thesis, Medical University of Ardabil 2004.

21. Mansouri-targhabeh $\mathrm{H}$ and Badie $\mathrm{Z}$, 'Transfusion-Transmitted Viruses in Individuals with Thalassaemia Major at Northeastern Iran, a Retrospective Sero-Epidemiological Survey', IJBC2008; 1; 1-4.

22. Hashemizadeh $\mathrm{H}$, Noori $\mathrm{R}$ and Kolagari SH, 'Assessment Hepatomegaly and liver Enzymes in 100 Patients with beta Thalassaemia Major in Mashhad Iran', Iranian Journal of Pediatric Hematology Oncology2012; 12(4); 171-177. 